\title{
ALA candidates on ACRL
}

\section{The two candidates for ALA president share their views on academic and research librarianship.}

$\mathbf{R}$ asked to giv and academic librarianship in general for this special C $d R L$ News feature. Their statements may aid you when you vote for ALA officers on this spring's ballot.

\section{Patricia W. Berger:}

I shall discuss briefly three problems which I believe are critical to the prosperity of academic librarians and libraries.

First, library preservation is an immense national problem which deserves substantial attention and effort. We must concern ourselves not only with restoration and storage problems but also with finding remedies to prevent future deterioration. ALA and ACRL can take some steps immediately to help the present

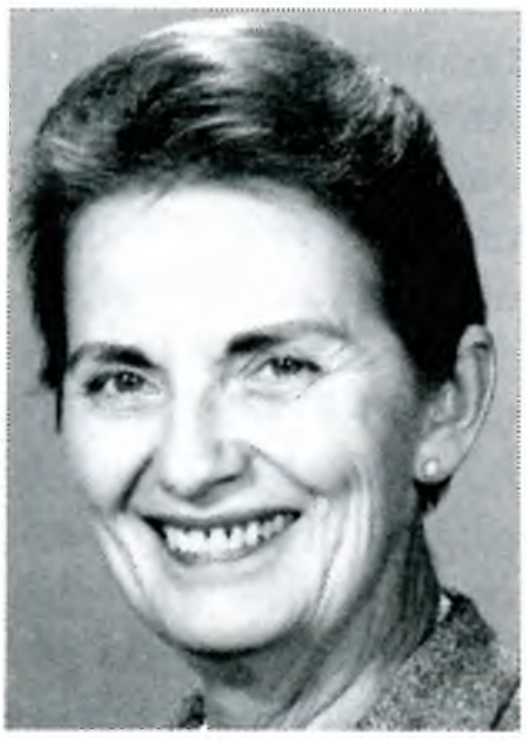

Patricia Berger situation.

-We should devise ways to acknowledge publicly efforts to curb deterioration of the written record. For example, the National Information Standards Organization's 1984 Standard for Permanent Paper is an example of an excellent preventive standard, but one which is costly to implement. Therefore, when a publisher adopts such a measure, she or he deserves public recognition and thanks for conducting business in a responsible, concerned manner.

-We must continue and increase efforts to iden- tify the literatures of those disciplines that need prompt restoration or require prompt adoption of deterioration preventive measures. Health sciences librarians have commenced to communicate their concern to medical publishers about the crumble and the rot of the biomedical literature; they are pressing for remedial measures. It seems to me that, working with the new Commission on Preservation and Access, ALA and ACRL can mount similar efforts in other disciplines of national importance.

- We must find ways to increase the public's awareness of the need for effective library resources preservation. The film "Slow Fires" is an excellent beginning. In addition, last October, CLR and its Commission on Preservation and Access convened a day-long meeting to discuss preserving the scientific and technical literature. The attendees at that meeting observed first, that an upsurge in public interest in preserving historic buildings generated "the expansion of historic preservation as an important national ethic" and second, that a similar event needs to happen if we are to achieve "success for the preservation of library materials." Seven ACRL members participated in that meeting. I believe such commitment must continue and should receive widespread ALA support.

Second, we must learn to handle "fallout" issues more constructively. By this I mean the deleterious "fallout" effects which result from unanticipated or unannounced shifts in economic policy and practice. For example, massive fallout to library purchasing power resulted from the double whammy delivered by the Administration's decision to let the dollar's value decline plus the foreign publishers' decision to institute differential pricing policies which gouged U.S. libraries. In many insti- 
tutions (including my own) the damage was further compounded by local bean-counters who failed to adjust library budgets in order to ameliorate at least some of the devastation. We must do a better job of appraising the national scene so as to anticipate such events before they occur and, whenever possible, take preventive action. If we are to influence such occurrences before fallout begins, we need to forge economic coalitions "for the public good." Given the present emphasis on education and literacy, the second White House Conference may provide a place and time to push our case in this regard.

Third, we must continue to resist and if possible stop attempts to control access to the resources of academic libraries. The staff at Columbia University's Mathematics and Science Library deserves high praise for resisting the FBI in its efforts to examine Library records in order to limit foreign access to Library resources. Still, the pressures continue. On February 15, Library Hotline reported a Department of Energy's deal-with-strings-

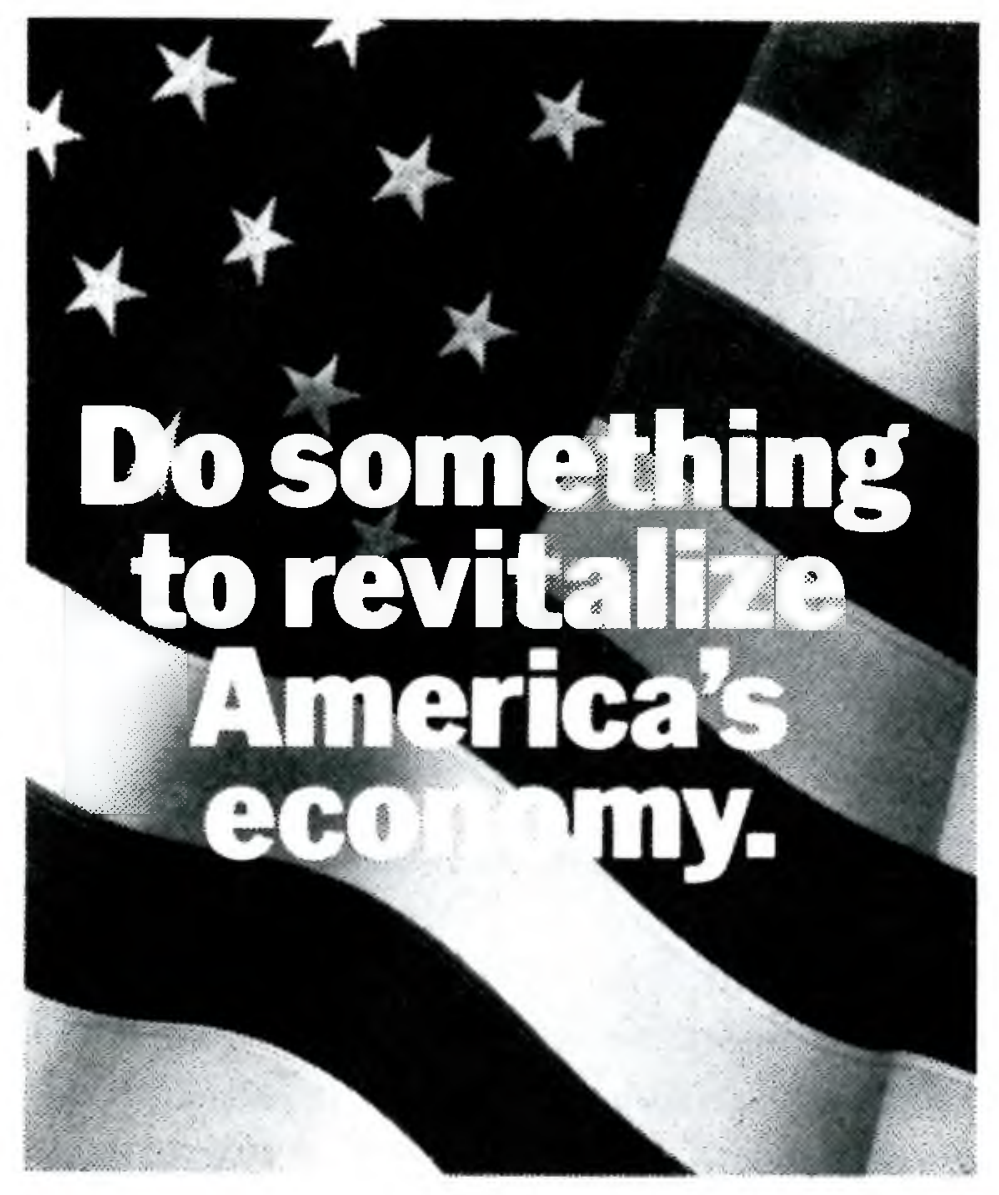

Support America's colleges. Because college is more than a place where young people are preparing for their future. It's where America - and American business - is preparing for its future.

\section{Give to the college of your choice.}

attached to Columbia. DOE agreed to ship copies of its reports to Columbia provided the Libraries agreed to limit availability of the reports to "government agencies and their contractors." Columbia declined the offer.

We are witnessing a return to a mind-set which characterized a distinctly unsavory period of our national life, namely the McCarthy era. Today, however, that mind-set is shared not by just a few individuals but by substantial components of a very large bureaucracy. Thus there is danger that such reasoning could become broadly rationalized and institutionalized within a relatively short time. For this reason, I believe that all components of ALA must resist any attempt to violate academic freedom.

I believe this country's libraries constitute its national knowledge base. I am committed to increasing public awareness of this indispensable national resource, because I want to see our nation's knowledge base afforded the protection, preservation and security that is at present reserved for our other national resources. To do this, I need your help. I ask for your support and for your vote.-Patricia W. Berger, Chief, Information Resources and Services Division, National Bureau of Standards, Gaithersburg, MD 20899.

\section{Rebecca T. Bingham:}

I have long admired the leadership role of ACRL, ALA's largest, financially strongest unit. I believe that the goal of any professional association is to enhance the profession it represents and the talents and abilities of its members. By this measure, ACRL's record is outstanding. It has not only provided a model of standards, long-range planning and effective use of the chapter system for ALA, but ACRL has played a strong leadership role in ALA through the service of its members and officers on

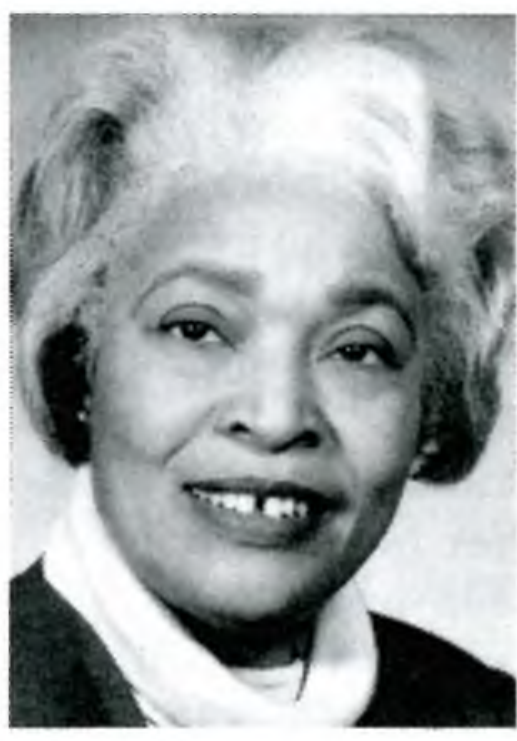

Rebecca Bingham Council, in the units, on the committees, and on the round tables.

At the risk of sounding dramatic, I can say that I have a long-standing love affair and identification with academic libraries. I attribute my being a librarian today to the rich and challenging experiences I was privileged to enjoy as an undergraduate student working my way through college as a page in the Circulation Department of the stately, vineclad original library beside the main entrance to Indiana University. I began working there for the 32 hours per week that I needed to stretch my meager resources to cover my college expenses when I was a freshman. By the time I was a junior, I was 
frequently assigned to be "in charge" of the Circulation Department on Saturday and Sunday afternoons. One day I realized the rewards I felt on this fringe of librarianship and suspected I might enjoy being a librarian more than the career in psychiatric social work for which I was preparing. In response to my question regarding my employment prospects should I change fields, Margaret Rufsvold of the Graduate Library School (its name then) informed me that library schools were preparing only about $10 \%$ of the librarians anticipated to be needed for the next ten years, and that for minority librarians, less than one-tenth of one percent. I made my decision on the spot, and have never looked back!

My first years of professional experiences were in various administrative roles in academic libraries-at Alcorn A \& M College in Mississippi, Tuskegee Institute in Alabama, and Jarvis Christian College in Texas. I see academic librarianship as the upward extension or the next level in the continuum which begins with librarianship in the elementary and secondary schools which are the focus of my current and longest professional service.

I have served on the extension faculty of the University of Kentucky School of Library and Information Science and have been a workshop leader and guest lecturer in the library and information science schools at a number of institutions.

While serving on President Carter's Advisory Committee for the 1979 White House Conference on Library and Information Services I was privileged to focus on the participation of academic/research librarians and librarians serving children and young people in a unique way.

While serving in the ALA Council (I am now in my second term), on the ALA Executive Board, as President of the Kentucky Library Association, and as President of the Southeastern Library Association I have maintained an up-to-date knowledge of the issues and concerns facing academic librarianship and I have a track record of addressing them through committee appointments, task forces, appeals to legislators and other appropriate means as the specific circumstances have warranted.

My interest in fostering access to information extends to all of librarianship, and certainly to academic and research libraries. Academic freedom, an openness that precludes misinformation, is basic to the excellence which is the ACRL goal for aca- demic libraries, research and other specialized libraries. I am concerned that any move toward the privatization of government publishing poses a threat to the availability of information by and about our government at the precise time when we so desperately need better information and a good supply of quality resources in the teaching and learning of new decision-making skills. I am aware that changing college and university student populations, which now range from older adults who are enrolling to high school students using academic libraries, are requiring changed realities of outreach and service for the libraries in these institutions.

Academic and research libraries are as much affected by the dramatic changes in the racial, ethnic and cultural demographics of our population as are all types of libraries and the whole field of librarianship. Minority recruitment, the retention of minority librarians, and upward mobility of minorities in the profession are musts if our campus and research libraries are to remain relevant to and representative of the institutions and communities of which they are a part.

The profession of librarianship, ALA and ACRL, will continue to meet challenges. ALA and its divisions are already engaged in dialogue relating to the new operating agreement as it becomes a reality. Concerns will continue to arise. New issues will continue to emerge. We will continue to be challenged to find new directions and revise our goals to respond to the new conditions as we come to understand them. As president of ALA, I assure you that I have a history that reflects understanding of the problems and concerns of ACRL. I do not promise solutions to all problems or the resolution of all issues. I do pledge a vigorous pursuit of solutions and resolutions, and I promise your involvement in that pursuit. I pledge to speak out responsibly, on all matters related to ALA and its goals of helping the librarian, in academic/research libraries as well as in all other libraries, to succeed.

I pledge my support! I encourage your active participation in developing appropriate plans, actions, and responses! I solicit your vote!!Rebecca T. Bingham, Director of Library Media Services, Jefferson County Public Schools, Durrett Education Center, 4409 Preston Highway, Louisville, KY 40213.

\section{ACRL executive summary}

\section{Professional development}

Plans are proceeding for the WESS Florence Conference, to be held April 4-8. There are over 100 registrants, about 20 of them from outside the United States. Travel arrangements are firmed up for flights from New York and Los Angeles, and for ground transportation from Milan to Florence. The program is wonderful, with national and international agencies well represented. A follow-up report will appear in $C \triangleleft R L N e w s$.

Cincinnati plans are exciting. Publicity and promotional activity includes new letterhead, post-it notes, a regular column in $C \mho R L$ News. 
CE101, Librarians as Supervisors, was presented by Maureen Sullivan in Syracuse, New York, as a local presentation. Despite awful weather, 57 people attended.

\section{Service}

Contract negotiations are underway for the Manual of Output Measures for Academic Libraries.

Advisory information is provided regularly to members and non-members on a variety of topics. To give a flavor of the "reference work" done, here are a few recent topics: names of theater library consultants; how to handle "problem student patrons" in academic libraries; mailing lists for media specialists; helping a Philadelphia Enquirer reporter prepare an article on academic libraries.

\section{Advocacy and liaison}

The third of three seminars on Campus Information Systems was held under the auspices of the Association of American Colleges and OCLC in Pomona, California, February 22-23. Eight colleges participated by sending teams including their president, vice president for academic affairs, computer center director, library director, and an interested faculty member. Results are an increased awareness of the technology and of the state of the art in "integrating" campus systems. The trend is toward centralizing administrative functions, decentralizing academic computing, and linking all through networking.
A mailing went to 1,600 STS members about the privatization of NTIS, encouraging them to take action on this crucial item.

\section{Research and publication}

The latest version of our current publications list has been published. The list includes 49 titles, as well as 19 free standards and guidelines.

Authorship work on Books for College Libraries is in the final stages. Pages will begin to be delivered to ALA Publishing in April. Special prepublication price is $\$ 375$ for all six volumes.

\section{Management}

The ACRL Budget for 1989 has officially been presented to ALA. According to decisions made by the Board at the Midwinter Meeting, we will reduce the fund balance by creating the Special Grants Fund and partly supporting the Output Measures Manual; other than those exceptions, revenues are projected to cover expenses.

The ACRL Budget and Finance Committee has been working on the ACRL Financial Plan. A draft will be ready for the ACRL Executive Committee this month.

The ACRL Quality Circle undertook a study of telephone service in the ACRL office area in order to improve both the service to callers and the way work is handled.-JoAn S. Segal, ACRL Executive Director.

\section{Candidates for ALA Council}

\section{These ACRL members need your vote.}

$\mathbf{T}$ he following members of the Association of College and Research Libraries are either nominated or petition candidates for ALA councilor in the spring 1988 elections. Members are encouraged to vote for these candidates to increase ACRL's voice in the affairs of the American Library Association.
Charles E. Beard, Ingram Library, West Georgia College, Carrollton.

Clarence Chisholm, Clinch Valley College, Wise, Virginia.

Lynn Scott Cochrane (McAuley), User Services, Virginia Polytechnic Institute and State University, Blacksburg. 